Artikel Riset

DOI : 10.33751/jf.v10i1.1717
Fitofarmaka Jurnal Ilmiah Farmasi

Vol.10, No.1, Juni $2020: 12-21$

p-ISSN : 2087-9164 e-ISSN : 2622-755X

\title{
UJI AKTIVITAS ANTIBAKTERI SABUN WAJAH EKSTRAK DAUN BELUNTAS (Pluchea indica L.) TERHADAP Propionibacterium acnes
}

\author{
Oom Komala $^{1 *}$, Septia Andini ${ }^{2}$, Fatimah Zahra ${ }^{3}$ \\ ${ }^{1}$ Program Studi Biologi, Fakultas Matematika dan Ilmu Pengetahuan Alam, \\ Universitas Pakuan, PO Box 452 Bogor, Indonesia 16143 \\ ${ }^{2}$ Program Studi Farmasi, Fakultas Matematika dan Ilmu Pengetahuan Alam, \\ Universitas Pakuan, PO Box 452 Bogor, Indonesia 16143 \\ *E-mail: oom.komala@unpak.ac.id
}

\begin{abstract}
ABSTRAK
Propionibacterium acnes merupakan bakteri gram-positif berbentuk batang dan merupakan flora normal kulit yang ikut berperan dalam pembentukan jerawat. Sabun wajah lebih sering digunakan sebagai alternatif antijerawat karena telah dikenal masyarakat luas dan lebih praktis penggunaannya dan ekonomis. Penelitian ini bertujuan untuk mengkaji dan mengetahui sabun pembersih wajah antijerawat yang mengandung ekstrak daun beluntas yang paling efektif dalam menghambat pertumbuhan bakteri $P$. acne. Pada penelitian ini dilakukan penentuan nilai Konsentrasi Hambat Minimum (KHM) ekstrak daun beluntas terhadap bakteri $P$. acne selanjutnya dan formulasi sediaan sabun wajah ekstrak daun beluntas. Sediaan sabun wajah ini dilakukan uji mutu dan uji Lebar Daya Hambat (LDH). Hasil penelitian menunjukkan bahwa KHM ekstrak daun beluntas terdapat pada konsentrasi 5\%. Sediaan sabun wajah ekstrak daun beluntas memiliki aktivitas antibakteri terhadap $P$. acne danyang paling efektif menghambat bakteri $P$. acne adalah formula 3 dengan konsentrasi $15 \%$ dengan rata-rata LDH sebesar 13,5 mm. Hasil dari uji hedonik menunjukan formula 1 lebih unggul dibandingkan dengan formula lainnya.
\end{abstract}

Kata Kunci: Ekstrak daun beluntas, Propionibacterium acnes, sabun wajah

\section{ANTIBACTERIAL ACTIVITY TEST OF FACIAL SOAP Pluchea indica L. AGAINST Propionibacterium acnes}

\begin{abstract}
Propionibacterium acnes is a gram-positive bacteria and a normal flora of the skin that contributes to the formation of acne. Facial soap often used as an alternative to antiacne because it had been known to the wider community and more practical and economical. This research aims to analyze and know the soap facial cleanser anti-acne of $P$. indica leaf extract the most effective in inhibiting the growth of bacteria $P$. acne as causes acne vulgaris. The minimum inhibitory concentration (MIC) of leaf extract against the bacteria $P$. acnes has subsequently created a formula of the herbal leaf extract of the $P$. indica $\mathrm{L}$. These facial soap preparations are conducted quality tests and the inhibit zone (IZ) antibacterial. The results showed that the MIC of an extract $P$. indica L leaf is at a concentration of 5\%. The soap of Plucheaindica L leaf extract has
\end{abstract}


antibacterial activity against $P$. acne and most effectively inhibits the bacteria $P$. Acne was Formula 3 with a concentration of $15 \%$ an average of zone inhibition of $13.5 \mathrm{~mm}$. Results from the hedonic test were Formula 1 superior to other formulas.

Keywords: Pluchea idica L leaf extract, Propionibacterium acnes, facial soap

\section{PENDAHULUAN}

Jerawat merupakan penyakit yang sering terjadi pada permukaan kulit wajah, leher, dada dan punggung. Jerawat muncul pada saat kelenjar minyak kulit terlalu aktif, sehingga pori-pori kulit akan tersumbat oleh timbunan lemak yang berlebihan (Sawarkar et al., 2010). Pengobatan jerawat dilakukan dengan cara memperbaiki abnormalitas folikel, menurunkan produksi sebum, menurunkan jumlah koloni Propionibacterium acnes atau hasil metabolismenya dan menurunkan inflamasi pada kulit. Populasi bakteri $P$. acnes dapat diturunkan dengan memberikan suatu zat anti bakteri seperti eritromisin, klindamisin, dan tetrasiklin (Harahap, 2000) P. acnes merupakan bakteri gram positif berbentuk batang dan merupakan flora normal kulit yang ikut berperan dalam pembentukan jerawat. $P$. acnes mengubah asam lemak tak jenuh menjadi asam lemak jenuh yang menyebabkan sebum menjadi padat. Jika produksi sebum bertambah, $P$. acnes juga akan bertambah banyak yang keluar dari kelenjar sebasea, karena P.acnes merupakan pemakan lemak (Harahap, 2000). Bakteri tersebut menyebabkan hiperproliferasi epidermis folikuler mengakibatkan obstruksi folikel, produksi sebum berlebihan, peradangan, dan peningkatan aktivitas bakteri (Macdonald, 2018).

Sabun wajah lebih sering digunakan sebagai alternatif antijerawat karena telah dikenal masyarakat luas dan lebih praktis penggunaannya dan ekonomis (Suryana, 2013), serta menghasilkan busa yang lembut untuk penggunaan pada wajah
(Sari \& Novita, 2014). Beluntas (Pluchea indica $L$ ) merupakan salah satu tanaman obat tradisional yang cukup tersebar luas di Indonesia. Hasil penelitian yang dilakukan oleh Rahmi et al., (2015), diketahui bahwa ekstrak etanol daun beluntas mempunyai aktivitas antibakteri terhadap $P$. acnes pada konsentrasi 5\%. Maka pada penelitian ini dibuat formula sabun wajah. Terhadap ekstrak dan formula sediaan sabun wajah ekstrak daun beluntas akan diuji Konsentrasi Hambat Minimum (KHM) terhadap bakteri $P$. acnes dan uji mutu serta uji Lebar Daya Hambat (LDH). Oleh karena itu penelitian ini bertujuan untuk mengetahui formula pembersih wajah yang paling efektif dalam menghambat pertumbuhan bakteri $P$. acne yang merupakan salah satu faktor penyebab acne vulgaris.

\section{METODE PENELITIAN}

\section{Alat dan Bahan}

Alat yang digunakan dalam penelitian ini yaitu $\mathrm{pH}$ meter (HANNA HI 2210-02), Viskometer Brookfield (DV - 1 prime), alat uji daya sebar, timbangan analitik, cawan petri, waterbath (H-WB3F-27L), vortex (Thermolyne Maxi Mix II), homogenaizer, vaccum rotary evaporator, kain batis, corong, maserator, kawat ose, autoklaf (Memert), bunsen, tabung reaksi, oven, moisture balance (AND MX 50), grinder (Philips HR2874). Bahan yang digunakan adalah daun beluntas yang diperoleh dari BALITRO, etanol 96\%, asam stearat, sodium lauril sulfat ( $\mathrm{SLS}$ ), $\mathrm{NaCl}$, gliserin, adeps lanae, trietanolamin (TEA), nipagin, serbuk magnesium, asam 
klorida, pereaksi wagner, larutan timbal asetat, serbuk seng, $\mathrm{FeCl} 3$. aquadest, nutrient agar, bakteri $P$. acnes dari Laboratorium Biologi Institut Pertanian Bogor, Klindamycin.

\section{Pembuatan Ekstrak}

Daun beluntas segar dicuci dengan air mengalir kemudian ditiriskan. Selanjutnya dikeringkan dalam oven $70^{\circ} \mathrm{C}$. Setelah kering dibuat serbuk menggunakan blender selanjutnya diayak dengan mest 100. Serbuk simplisia yang diperoleh disimpan dalam wadah tertutup. Sebanyak 300 g serbuk simplisia kering, dimasukkan pada maserator lalu ditambahkan etanol $96 \%$ sebanyak 3000 ml (1:10), didiamkan selama 1 jam dan sesekali dilakukan pengadukan dan dikocok selama 30 menit dilakukan sebanyak 3 kali lalu disimpan pada suhu ruang selama 24 jam. Proses ekstraksi maserasi dilakukan selama 3 x 24 jam dengan perlakuan yang sama, dilakukan penyaringan setelah diinap tuangkan lalu filtrat yang terkumpul dipekatkan menggunakan alat vaccum evaporatory sehingga didapat ekstrak kental (DepKes, 2013).

\section{Uji KHM Ekstrak Daun Beluntas}

Penentuan konsentrasi hambat minimum dilakukan dengan metode difusi agar. Media agar steril didinginkan sampai suhu $\pm 45^{\circ} \mathrm{C}$ kemudian dimasukkan kedalam cawan petri masingmasing sebanyak $15 \mathrm{~mL}$ dan ditambahkan bakteri uji konsentrasi $10^{-6}$ sebanyak 0,2 $\mathrm{mL}$ disebar diatas permukaan agar-agar, setelah itu ekstrak daun beluntas dengan konsentrasi 2\%, 3\%, 4\%, dan 5\% sebanyak $1 \mathrm{~mL}$ dimasukkan ke dalam masing-masing cawan petri kemudian dihomogenkan. Cawan petri tersebut diinkubasi dalam sungkup anaerob selama 3 x 24 jam pada suhu $37^{\circ} \mathrm{C}$.
Setelah diinkubasi dilihat dan diamati adanya pertumbuhan koloni bakteri atau tidak. Konsentrasi terendah dimana tidak terjadi pertumbuhan bakteri pada cawan petri merupakan konsentrasi hambat minimum (KHM) (Radji, 2016).

\section{Formulasi Sediaan Sabun Wajah}

Formula sabun wajah mengacu pada penelitian yang dilakukan oleh Nurama \& Suhartiningsih (2014), formula seperti pada Tabel 1. Masingmasing bahan yang diperlukan ditimbang sesuai yang tertera pada tabel 1. Ekstrak daun beluntas dengan konsentrasi tertentu diambil lalu dilarutkan dalam air panas $100^{\circ} \mathrm{C}$ (masa 1). Sodium Lauryl Sulfat (SLS) dilarutkan didalam air lalu diaduk hingga homogen, $\mathrm{NaCl}$ ditambahkan dan diaduk hingga homogen (masa 2). Asam stearat dan gliserin dilarutkan dengan pemanasan. Setelah sama-sama larut, adeps lanae dicampurkan kedalamnya dan diaduk hingga homogen (masa 3). Masa 1, masa 2, dan masa 3 dicampurkan menjadi satu lalu diaduk hingga homogen tambah aquadest $100 \mathrm{ml}$ kemudian diaduk menggunakan alat homogenaizer dengan kecepatan $500 \mathrm{rpm}$ selama 30 menit. Campuran didinginkan pada suhu ruang. Sediaan sabun wajah kemudian dimasukan kedalam wadah bersih yang sudah disterilkan sebelumnya.

\section{Evaluasi Sediaan}

\section{Pengujian Organoleptis}

Uji sifat fisik sabun wajah dilakukan dengan pengamatan terhadap organoleptis yang meliputi penampilan, bau, dan warna (DepKes, 1979)

\section{Pengujian pH}

Pengukuran $\mathrm{pH}$ dilakukan dengan menggunakan $\mathrm{pH}$ meter. Sebelum digunakan alat $\mathrm{pH}$ meter dikalibrasi dengan larutan buffer ( $\mathrm{pH} 4,7-9,0)$ setiap 
akan dilakukan pengukuran. Pengujian dilakukan sebanyak 2 kali pada masingmasing formula. Formula harus memenuhi rentang $\mathrm{pH}$ dengan kisaran sesuai dengan $\mathrm{pH}$ kulit yaitu antara $\mathrm{pH} 8$ -
11. Sehingga aman untuk diaplikasikan pada kulit karena pada $\mathrm{pH}$ tersebut diharapkan tidak terjadi iritasi pada kulit (SNI, 1996).

Tabel 1. Formulasi Sabun Wajah

\begin{tabular}{lllll}
\hline Bahan & $\mathrm{F} 0(\%)$ & $\mathrm{F} 1(\%)$ & $\mathrm{F} 2(\%)$ & $\mathrm{F} 3(\%)$ \\
\hline Ekstrak daun beluntas & - & 5 & 10 & 15 \\
Asam Sitrat & 2,50 & 2,50 & 2,50 & 2,50 \\
Sodium Lauryl Sulfat & 12,50 & 12,50 & 12,50 & 12,50 \\
$\mathrm{NaCl}$ & 1,67 & 1,67 & 1,67 & 1,67 \\
Gliserin & 0,70 & 0,70 & 0,70 & 0,70 \\
Adeps lanae & 0,50 & 0,50 & 0,50 & 0,50 \\
Aquadest Hingga & 100 & 100 & 100 & 100 \\
\hline
\end{tabular}

Keterangan: - Tidak mengandung ekstrak daun beluntas

\section{Pengujian Daya Busa}

Daya busa diukur dengan melarutkan sediaan dalam air, kemudian dilakukan pengocokan dengan vorteks selama 2 menit, tinggi busa yang terbentuk diukur (Lunkenheimer \& Malysa, 2003).

\section{Pengujian Daya Sebar}

Daya sebar dilakukan dengan menindih $0,5 \mathrm{~g}$ sediaan dengan beban hingga $50 \mathrm{~g}$ selama 1 menit, kemudian dicatat diameter tiap penambahan beban hingga konstan. Uji daya sebar yang baik sesuai persyaratan yaitu $3-5 \mathrm{~cm}$.

\section{Pengujian Viskositas}

Sampel diuji viskositas dengan menggunakan Viscometer Brookfield. Sampel yang diuji ditempatkan dalam wadah penampung bahan, wadah diatur ketinggiannya sehingga spindle dapat bergerak (dipilih spindle 3 yang sesuai dengan tingkat kekentalan sabun cair). Viskometer dinyalakan dan dicatat nilai viskositas yang tertera pada alat viskometer tersebut (Laksana, dkk. 2017).

\section{Pengujian Panelis}

Uji panelis ini dilakukan terhadap 20 panelis yang akan menilai formula mana yang terbaik dilihat dari parameter aroma, warna dan tektur. Setiap panelis menguji 4 formula, kemudian panelis diwajibkan memberikan nilai berkisar antara 1 sampai 4. Sediaan sabun wajah dioleskan pada permukaan kulit tangansecukupnya sampai rata sempurna kemudian diberikan penilaian yang meliputi : Aroma, warna, dan tekstur.

\section{Uji LDH Formula Sabun Wajah Terhadap bakteri}

Pengujian ini untuk mengetahui lebar daerah hambat sabun wajah ekstrak daun beluntas yang dibandingkan dengan aktivitas kontrol positif dan negatif. Pada penelitian ini menggunakan metode difusi cakram. Larutan kontrol positif yang digunakan yaitu klindamisin (10 ppm) 30 $\mu \mathrm{l} /$ disk sedangkan larutan kontrol negatif adalah basis sabun. Inokulum mikroba dari hasil pengenceran diambil sebanyak $0,2 \mathrm{~mL}$ konsentrasi $10^{-6}$ dicampur ke dalam media NA kemudian dihomogenkan agar mikroba menyebar merata. Kertas cakram yang sudah berisi larutan uji dan kontrol diletakkan di atas 
media, kemudian disimpan dalam inkubator pada suhu $37^{\circ} \mathrm{C}$ selama 24 jam. Setelah diinokulasi, pada masing-masing konsentrasi diamati sekeliling kertas cakramnya dan diukur lebar diameter hambat (LDH) yang terbentuk. Pengujian ini dilakukan 3 kali pengulanga, kemudian diinkubasi selama 3 hari pada suhu $37^{\circ} \mathrm{C}$. Lebar daerah hambat diukur disekitar cakram (Kumar, 2016).

\section{Parameter Penelitian}

1. Konsentrasi Hambat Minimum pada ekstrak daun beluntas.

2. Evaluasi mutu sabun wajah yang terdiri dari uji organoleptik, uji $\mathrm{pH}$, uji daya busa, uji daya sebar, uji viskositas, uji panelis dan uji antibakteri LDH (Lebar Daerah Hambat).

\section{Analisis Data}

Data dianalisis untuk mengetahui perbedaan nilai Lebar Daerah Hambat (LDH) pertumbuhan bakteri dari sediaan sabun wajah ekstrak daun beluntas dengan membandingkan 3 formula yang berbeda dan akan dianalisis dengan menggunakan Analisis Variansi (ANOVA) menggunakan metode eksperimental Rancangan Acak Lengkap (RAL). Sebanyak 5 perlakuan dengan 3 kali ulangan. Perlakuan tersebut adalah 3 perlakuan sebagai formula sediaan sabun wajah ekstrak daun beluntas, 1 perlakuan sebagai kontrol positif (klindamisin 10 ppm), dan 1 perlakuan sebagai kontrol negatif (basis sabun wajah) dan dilakukan ulangan sebanyak 3 kali.

\section{HASIL DAN PEMBAHASAN Hasil Ekstrak Daun Beluntas}

Hasil pengeringan daun beluntas sebanyak $5 \mathrm{~kg}$ diperoleh serbuk simplisia (Gambar 1A) sebanyak 1,1 kg dengan susut pengeringan simplisia sebesar 22,51 \%. Hasil ekstrak kental etanol (Gambar 1B) yang diperoleh dari $300 \mathrm{~g}$ serbuk daun beluntas adalah 48,65 $\mathrm{g}$ dan diperoleh rendemen sebesar 16,2\%. Berdasarkan hasil uji fitokimia simplisia dan ekstrak daun beluntas menunjukkan seperti pada Tabel 2.

Tabel 2. Hasil Uji Fitokimia Daun Beluntas

\begin{tabular}{|c|c|c|c|c|}
\hline \multicolumn{2}{|c|}{ Identifikasi Senyawa } & Parameter & $\begin{array}{c}\text { Hasil } \\
\text { analisis }\end{array}$ & Kesimpulan \\
\hline \multicolumn{2}{|c|}{ Saponin } & Busa yang stabil & Busa yang stabil & + \\
\hline \multicolumn{2}{|c|}{ Tanin } & Endapan putih & Endapan putih & + \\
\hline \multicolumn{2}{|c|}{ Flavonoid } & $\begin{array}{l}\text { Merah-ungu / } \\
\text { kuning oranye }\end{array}$ & kuning oranye & + \\
\hline \multirow{3}{*}{ Alkaloid } & Bouchardat & $\begin{array}{l}\text { Endapan Coklat } \\
\text { tua }\end{array}$ & $\begin{array}{l}\text { Endapan Coklat } \\
\text { tua }\end{array}$ & \\
\hline & Mayer & $\begin{array}{c}\text { Endapan } \\
\text { putih/kekuningan }\end{array}$ & Endapan putih & \\
\hline & Dragendorf & $\begin{array}{l}\text { Endapan Oranye } \\
\text { kecoklatan }\end{array}$ & $\begin{array}{l}\text { Endapan Oranye } \\
\text { kecoklatan }\end{array}$ & + \\
\hline
\end{tabular}

Keterangan : $(+)$ terdapat senyawa, (-) tidak terdapat senyawa 


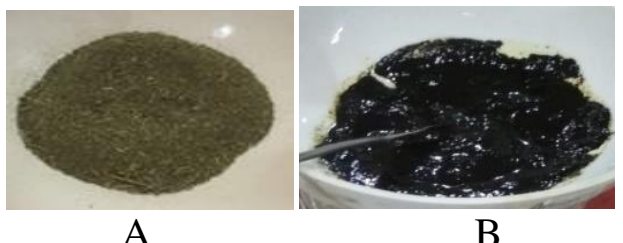

Gambar 1. Serbuk simplisisa (A) dan ekstrak (B) daun Beluntas

\section{Hasil Uji KHM Ekstrak Daun Beluntas Pada Pengujian Konsentrasi} Hambat Minimum (KHM) metode yang digunakan adalah metode difusi agar. Metode ini serupa dengan metode dilusi cair namun menggunakan media padat (agar). Keuntungan metode ini adalah satu konsentrasi agen antimikroba yang diuji dapat digunakan untuk menguji beberapa mikroba uji (Pratiwi, 2008). Hasil pengujian diketahui bahwa konsentrasi ekstrak daun beluntas 5\% dapat menghambat pertumbuhan bakteri Propionibacterium acnes. Pada konsentrasi $5 \%$ tidak terlihat adanya pertumbuhan koloni (Gambar 2). Konsentrasi ini mencegah pertumbuhan mikroorganisme secara in vitro (Harmita \& Radji, 2008). Untuk mengetahui efektivitas formulasi sabun wajah dilakukan variasi konsentrasi yang lebih besar atau sama dengan 5\%.
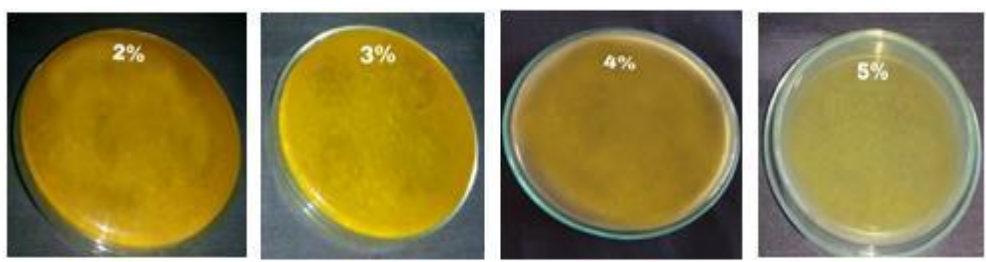

Gambar 2. Hasil uji KHM ekstrak daun Beluntas

Uji Konsentrasi Hambat Minimum (KHM) Ekstrak Daun Beluntas

Pada Pengujian Konsentrasi Hambat Minimum (KHM) metode yang digunakan adalah metode dilusi padat. Metode ini serupa dengan metode dilusi cair namun menggunakan media padat (agar). Keuntungan metode ini adalah satu konsentrasi agen antimikroba yang diuji dapat digunakan untuk menguji beberapa mikroba uji (Pratiwi, 2008). Deret konsentrasi ekstrak daun beluntas yaitu $2 \%, 3 \%, 4 \%, 5 \%$. Hasil pengujian diketahui bahwa konsentrasi ekstrak daun beluntas $5 \%$ dapat menghambat pertumbuhan bakteri Propionibacterium acnes.

\section{Hasil Evaluasi Sediaan}

Berdasarkan hasil organoleptik pada parameter penampilan dari ketiga formula memiliki penampilan yang berbeda, seperti terlihat pada Tabel 3 . 
Tabel 3. Hasil Uji Organoleptik Formula Sabun Wajah

\begin{tabular}{ccll}
\hline Formula & $\mathrm{pH}$ & Warna & Kekentalan \\
\hline 1 & 3,686 & hijau tua & kental \\
2 & 4,691 & hitam & Sedikit kental \\
3 & 5,152 & hitam & Sedikit encer \\
\hline
\end{tabular}

Keterangan : $\mathrm{pH}$ basis sabun 6,5

Adanya perbedaan konsentrasi ekstrak daun beluntas menunjukkan semakin tinggi konsentrasi maka sediaan yang diperoleh semakin tidak kental. Pada parameter warna formula 2dan 3 memiliki warna yang sama yaitu hitam sedangkan untuk formula 1 berwarna hijau tua.. Pada parameter bau ketiga formula memiliki bau yang sama yaitu wangi khas daun beluntas dan wangi green tea karena ada sedikit penambahan pewangi yang berasal dari minyak atsiri teh hijau.

\section{Hasil Pengujian pH}

Berdasarkan hasil pengujian $\mathrm{pH}$ untuk basis sabun memiliki $\mathrm{pH}$ 6,5 sedangkan ketiga formula memiliki nilai $\mathrm{pH}$ yang berbeda-beda, dibawah $\mathrm{pH}$ basis sabun (Tabel 3). Perbedaan ini disebabkan karena ekstrak daun beluntas memiliki sifat basa. Semakin tinggi konsentrasi maka semakin besar nilai $\mathrm{pH}$. Jika sediaan memiliki $\mathrm{pH}$ yang terlalu basa maka dapat menyebabkan kulit menjadi kering, sedangkan jika $\mathrm{pH}$ terlalu asam akan menimbulkan iritasi kulit (R. Sari \& Ferdinan, 2017).

\section{Hasil Pengujian Daya Sebar}

Pada sediaan sabun wajah harus seperti semifluid yang berarti hasil dari uji daya sebar harus masuk rentang 5-7 cm. Berdasarkan hasil pengujian daya sebar, hanya formula 1 yang tidak masuk dalam rentang tersebut. Hal ini dapat disebabkan karena sediaan sabun wajah yang kental dan memiliki konsentrasi yang kecil.
Daya sebar berbanding terbalik dengan viskositas, semakin tinggi viskositas maka daya sebar yang didapat semakin kecil (Eugresya et al., 2017). Viskositas yang rendah menyebabkan kemampuan mengalir sediaan lebih tinggi yang memungkinkan sediaan dapat menyebar dengan mudah dan terdistribusi rata. Hasil analisa menunjukkan nilai tinggi busa berbeda. Formula 1 memiliki busa yang lebih tinggi dibandingkan formula 2 dan formula 3. Hal ini menunjukan bahwa setiap penambahan ekstrak dapat menurunkan tinggi dari busa.

\section{Hasil Pengujian Viskositas}

Hasil uji viskositas menunjukkan bahwa formula 1,2, dan 3 bertutut-turut memiliki nilai viskositas 2791, 2207, dan 1291. Semakin tinggi konsentrasi ekstrak daun beluntas maka nilai viskositas semakin kecil dan sedian semakin cair. Viskositas sabun cair yang dipersyaratkan oleh SNI yaitu 500 - 20.000 cPs dan hasil viskositas yang telah dilakukan memenuhi syarat SNI (Standar Nasional Indonesia, 1996).

\section{Hasil Pengujian Organoleptis}

Uji kesukaan dilakukan terhadap parameter aroma, warna, dan tekstur terhadap tiga formula sabun wajah. Pengujian dilakukan oleh 20 orang panelis baik perempuan maupun laki-laki pada usia 20-25 tahun. Data hasil kuisioner yang diisi oleh panelis diolah dengan program SPSS 18. Hasil pada Tabel 4. 
Tabel 4. Hasil Uji Kesukaan Sabun Wajah

\begin{tabular}{ccccc}
\hline Formula & Aroma & Warna & Tekstur & Rata rata \\
\hline F 1 & $3,15^{\mathrm{a}}$ & $4,10^{\mathrm{b}}$ & $3,00^{\mathrm{a}}$ & 3,42 \\
F2 & $2,90^{\mathrm{a}}$ & $3,25^{\mathrm{a}}$ & $3,25^{\mathrm{a}}$ & 3,13 \\
F3 & $2,95^{\mathrm{a}}$ & $3,30^{\mathrm{a}}$ & $3,35^{\mathrm{a}}$ & 3,2 \\
\hline \multicolumn{2}{l}{ Keterangan : huruf superskrip yang sama menunjukkan tidak berbeda nyata }
\end{tabular}

\section{Hasil Uji Hedonik}

Hasil uji hedonik pada parameter aroma dari ketiga formula memiliki aroma yang tidak berbeda nyata. Pada parameter warna formula 1 berbeda nyata dengan formula 2 dan formula 3 , sedangkan formula 2 dan formula 3 tidak berbeda nyata. Hal ini karena konsentrasi ekstrak yang berbeda pada setiap formula. Formula 2 dan formula 3 memiliki konsentrasi ekstrak daun beluntas yg tinggi dibandingkan formula 1 sehingga menghasilkan warna yang lebih pekat. Parameter tekstur dari ketiga formula memiliki tekstur yang tidak berbeda nyata. Dari hasil uji hedonik menunjukan bahwa formula 1 merupakan formula yang paling disukai panelis (Tabel 4). Walaupun daya antibakteri $\mathrm{F}_{1}$ lemah sebagai sabun wajah, baik digunakan untuk perawatan sehari-hari.

\section{Hasil Uji Lebar Daerah Hambat (LDH) Sabun Wajah}

Pengujian lebar daerah hambat terhadap sediaan sabun wajah ekstrak daun beluntas pada bakteri Propionibacteriumacnes dan antibiotik klindamisin sebagai kontrol positif dan basis sabun sebagai kontrol negative (Gambar 4). Zona daya hambat terlihat setelah diinkubasi, dimana daerah bening sekitar cakram menunjukan koloni bakteri pada daerah itu mati atau tidak berkembang. Reaksi dengan sampel dan antibiotik membuat pertumbuhan koloni bakteri disekitarnya berhenti, sehingga daerah disekitar sampel dan antibiotik berwarna lebih cerah dari wilayah medium agar yang ditumbuhi bakteri, adanya diameter zona hambat yang terbentuk pada media (Khusuma dkk., 2019).

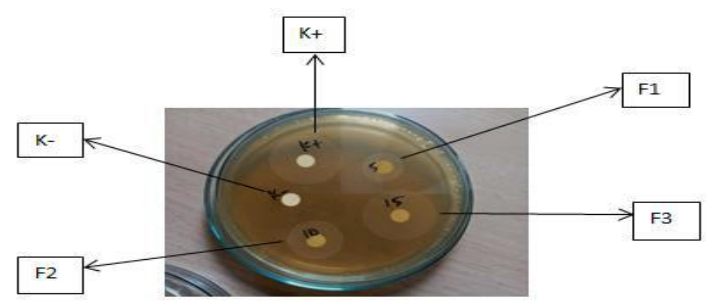

Gambar 3. LDH sediaan sabun wajah Keterangan :

$\mathrm{F} 1=$ Formula $1, \mathrm{~F} 2=$ Formula $2, \mathrm{~F} 3=$ Formula 3 $(+)=$ Kontrol Positif (Klindamisin)

$(-)=$ Kontrol Negatif $($ Basis $)=F_{0}$

Dari hasil tersebut menunjukkan bahwa sabun wajah ekstrak daun beluntas pada formula 1 , formula 2 , dan formula 3 memiliki aktivitas menghambat pertumbuhan bakteri $P$. acnes. Bakteri $P$. acnes adalah bakteri gram-positif mengandung lapisan peptidoglikan, yang merupakan penghalang permeabilitas efektif, sementara gram-negatif bakteri dikelilingi oleh membran luar tambahan senyawa lipopolysaccharide struktural, yang membuatnya kedap lipofilik untuk zat terlarut dan porins, maka merupakan penghalang selektif untuk zat terlarut hidrofilik (Osuntokun, 2018). Dalam hal ini $P$. acnes lebih mudah terhambat dibandingkan dengan bakteri Gramnegatif. Berdasarkan hasil pengujian terlihat dimana semakin tinggi konsentrasi ekstrak pada formula maka semakin besar daerah hambat yang diperoleh. Sedangkan pada basis sabun tampak ekstrak daun beluntas tidak membentuk zona hambat. Zona hambat 
dari kontrol positif (klindamisin) hampir sama besarnya dengan Formula 3, hal ini menunjukan bahwa kontrol positif (klindamisin) berpengaruh pada bakteri $P$. acnes sehingga aktifitas penghambatannya tergolong dalam kategori kuat. Pada $\mathrm{F}_{3}$ sebagai sabun tidak baik digunakan untuk sehari-hari, karena aktivitasnya secara statistik sama dengan antibiotik Klindamisin. $F_{3}$ sangat sesuai jika digunakan sebagai obat untuk kulit yang mengalami infeksi. Terbentuknya zona hambat disekitar cakram diduga karena ekstrak daun beluntas mengandung flavonoid. Flavonoid juga bersifat bakteriostatik yang bekerja melalui penghambatan sintesis dinding sel bakteri (Soedibyo, 1998). Nilai diameter daerah hambat yang diperoleh dianalisis menggunakan Rancangan Acak Lengkap (RAL). Berdasarkan analisis ragam terhadap $P$. acnes memberikan hasil yang berbeda nyata. Dari Tabel 5 dapat disimpulkan bahwa aktivitas antiacne sabun wajah dengan Formula 3 sebanding dengan klindamisin berdasarkan nilai lebar daya hambatnya.

Tabel 5. Nilai Lebar Daerah Hambat (LDH) Sediaan Sabun Wajah

\begin{tabular}{lc}
\hline Perlakuan & $\begin{array}{c}\text { Nilai LDH } \\
(\mathrm{mm})\end{array}$ \\
\hline Kontrol (-) & $0,00^{\mathrm{a}}$ \\
Kontrol (+) & $13,3^{\mathrm{d}}$ \\
Formula 1 & $8,50^{\mathrm{b}}$ \\
Formula 2 & $11,5^{\mathrm{c}}$ \\
Formula 3 & $13,5^{\mathrm{d}}$ \\
\hline
\end{tabular}

Catatan : huruf yang sama pada superscript pada kolom yang sama menunjukkan hasil tidak berbeda nyata, sedangkan huruf yang berbeda pada kolom yang sama menunjukkan hasil yang berbeda nyata.

Berdasarkan hasil uji lanjut Duncan menunjukkan konsentrasi ekstrak daun beluntas berpengaruh memperbesar Lebar
Daerah Hambat (LDH). Dari kelima perlakuan, kontrol (-) tidak memiliki pengaruh apapun terhadap setiap perlakuan. Pada kontrol (+) memiliki pengaruh yang sama dengan formula 3 namun berbeda dengan formula 1 dan 2 . Formula 3 memiliki lebar daerah hambat terbesar dibandingkan formula 1 , formula 2, dan kontrol positif. Seiring dengan bertambahnya konsentrasi ekstrak daun beluntas maka nilai daerah hambat semakin meningkat. Lebar daerah hambat sabun wajah ekstrak daun beluntas lebih besar dibanding dengan kontrol positifnya yaitu klindamisin $10 \mathrm{ppm}$. Hal ini dapat disebabkan karena pada ekstrak daun beluntas mengandung senyawa flavonoid yang efektif menghambat pertumbuhan bakteri. Sedangkan pada kontrol negatif yaitu basis sabun tidak memberikan efek antibakteri terhadap bakteri P. acnes.

\section{KESIMPULAN}

Sediaan sabun wajah ekstrak daun beluntas memiliki aktivitas antibakteri terhadap bakteri Propionibacterium acnes. Aktivitas antibakteri tertinggi terdapat pada fomula 3 dengan konsentrasi ekstrak daun beluntas $15 \%$ dengan LDH sebesar 13,5 mm sebanding dengan klindamisin dengan LDH sebesar 13,3. Formula 1 dengan ekstrak daun beluntas konsentrasi 5\% disukai panelis namun tidak memenuhi syarat uji mutu sediaan.

\section{Ucapan Terima Kasih}

Terima kasih disampaikan kepada Kepala Laboratorium Farmasi, Fakultas Matematika dan Ilmu Pengetahuan Alam, Universitas Pakuan, Bogor dan Laboratorium Biologi Institut Pertanian Bogor atas bantuannya yang telah memberikan kesempatan untuk menggunakan laboratorium penelitian. 
DAFTAR PUSTAKA

Departemen Kesehatan, R. I. 1979. Materia Medika Indonesia. Direktorat Jenderal Pengawasan Obat dan Makanan.

Departemen Kesehatan, R. I. 2013. Suplemen III. In Farmakope Herbal (Edisi I).

Eugresya, G., Avanti, C., \& Uly, S. 2017. Pengembangan Formula dan Uji Stabilitas Fisik-pH Sediaan Gel Facial Wash yang Mengandung Ekstrak Etanol Kulit Kayu Kesambi. Media Pharmaceutica Indonesia, 1(4), 181-188.

Harahap, M. 2000. Ilmu Penyakit Kulit, Acne Vulgaris. Hipokrates.

Harmita, \& Radji, M. 2008. Analisis Hayati Buku Ajar Program Studi Farmasi. Penerbit Buku Kedokteran EGC.

Kumar, S. 2016. Essentials of Microbiology. Jaypee Brothers Medical Publishers.

Macdonald, F. 2018. Researchers Might Have Figured Out Why Bacteria Only Causes Acne in Some People. In Science Alert.

Nurama, Y., \& Suhartiningsih. 2014. Pengaruh Penambahan Sari Belimbing Wuluh Terhadap Sifat Fisik Sediaan Sabun Wajah Berbentuk Cair. E-Journal, 3(1), 251-259.

Pratiwi. 2008. Mikrobiologi Farmasi. Erlangga.
Radji, M. 2016. Mekanisme aksi molekuler Antibiotik dan Kemoterapi. Penerbit Buku Kedokteran EGC.

Rahmi, A., Cahyanto, T., Sujarwo, T., \& Lestari, R. I. 2015. Uji aktivitas antibakteri ekstrak daun beluntas terhadap Propionibacterium acnes penyebab jerawat. Teknologi UIN Sunan Gunung Djati Bandung.

Sari, L. I., \& Novita, R. 2014. Formulasi Sabun Transparan Minyak YlangYlang dan Uji Efektivitas terhadap Bakteri Penyebab Jerawat. Journal Sains Farmasi \& Klinis, 1(1), 6171.

Sari, R., \& Ferdinan, A. 2017. Pengujian Aktivitas Antibakteri Sabun Cair dari Ekstrak Kulit Daun Lidah Buaya. Pharmaceutical Science Research, 4(3), 111-120.

Sawarkar, H. A., Khadabadi, S. S., Mankar, D. M., Faroqni, I. A., \& Jagtap, N. S. 2010. Development and Biological Evaluation of Herbal Anti Acne Gel. International Journal of PharmTech Research, 2(3), 28-31.

Standar Nasional Indonesia. 1996. Batas Maksimum Sabun Cair.

Suryana. 2013. Kewirausahaan Kiat dan Proses Menuju Sukses. Salemba Empat. 